\title{
THE RESULTS OF ISCHAEMIA IN CHEMICAL INJURIES
}

\author{
MARTIN REIM \\ Aachen, Germany
}

\begin{abstract}
SUMMARY
Severe burns of the anterior eye segment which include cornea, limbus and adjacent conjunctiva necrosis were accompanied by ischaemia. While necrotic conjunctival and subconjunctival tissue should be removed to eliminate its toxic influence, the opaque cornea and ischaemic sclera could not be removed. The ciliary body and the iris also suffer from ischaemic damage and under such conditions nutrient metabolites are deficient in the anterior segment of the eye. In the surrounding healthy tissues an inflammatory reaction begins after several days which induces an infiltration of the damaged tissues by leucocytes and an increase of $\mathrm{N}$-acetylglucosaminidase and Cathepsin-D as demonstrated in model experiments and in patients. These destructive enzymes are apparently involved in the corneal and corneo-scleral ulceration and their activities may therefore be used to assess the severity of the ocular burn.
\end{abstract}

It is well known that ischaemia accompanies chemical and thermal eye injuries. The extent of the ischaemia is considered to influence the prognosis; the wider and deeper the ischaemic area of the anterior eye segment, the worse the prognosis. ${ }^{1}$

The chemical injury destroys both the cells and the extracellular matrix causing necrosis of tissue. As the blood vessels also are destroyed, ischaemia results. Toxic substrates such as the prostaglandins, histamine, angiotensin, leukotrienes and others are released from the burnt cells. When they reach the surviving tissues by diffusion, an inflammatory response is initiated, which in the early stages is polymorphonuclear. After 10 days, lymphocytes and macrophages invade the necrotic tissues. ${ }^{2}$ This reaction not only removes the necrotic tissue but also induces ulceration to the extent that in severe cases the whole anterior segment may melt away. Alternatively, in the tissues bordering the necrotic area the inflammatory reaction may induce proliferation of cells for repair, which covers the necrotic areas giving rise to severe scarring.

\section{CLINCIAL SIGNS OF ISCHAEMIA}

Ischaemia in the anterior eye segment is often observed

Correspondence to: Professor Dr. Med. M. Reim, Direktor der Augenklinik der Medizinischen Fakultat Klinikum der RWTH Pauwelsstrasse 30 D-5100 Aachen. if the burn extends beyond the cornea and destroys the adjacent vascularised tissues. Small areas of ischaemia at the limbus eventually heal without consequence, but more extensive burns evoke considerable damage.

The tissues affected may include conjunctiva, episclera, the tarsi, the lid margins, the anterior sclera, and the cornea, and often result in anterior segment ischaemia. Figure 1 demonstrates ischaemia of the lower conjunctiva in severe alkali burn. In this case chemosis was seen. The blood column in the conjunctival vessels disappeared or did not show any movement. Figure 2a shows extended ischaemia of the whole anterior sclera two weeks after a total burn of the anterior segment with $30 \%$ sodium hydroxide.

The necrotic conjunctiva was sloughed away. The bare white sclera became visible. It was devoid of blood vessels. Adjacent, highly inflamed conjunctiva was seen. The intensity of a burn (depending upon the concentration and amount of the burning agent) may also affect the deeper parts of the eye.

The ciliary body may be damaged and become ischaemic by limbal penetration of the chemical. This results in a break down of the blood/aqueous barrier which is followed by exudation of proteins into the anterior chamber as indicated by a positive Tyndall phenomenon.

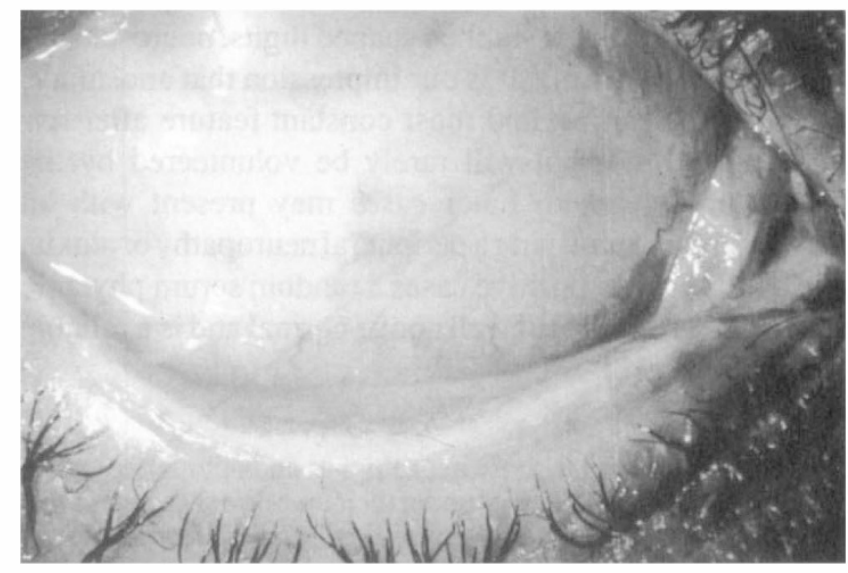

Fig. 1. Conjunctival ischaemia immediately following most severe alkali burn. Scarce blood vessels exhibit no blood flow. Conjunctional chemosis slitlamp photograph. 


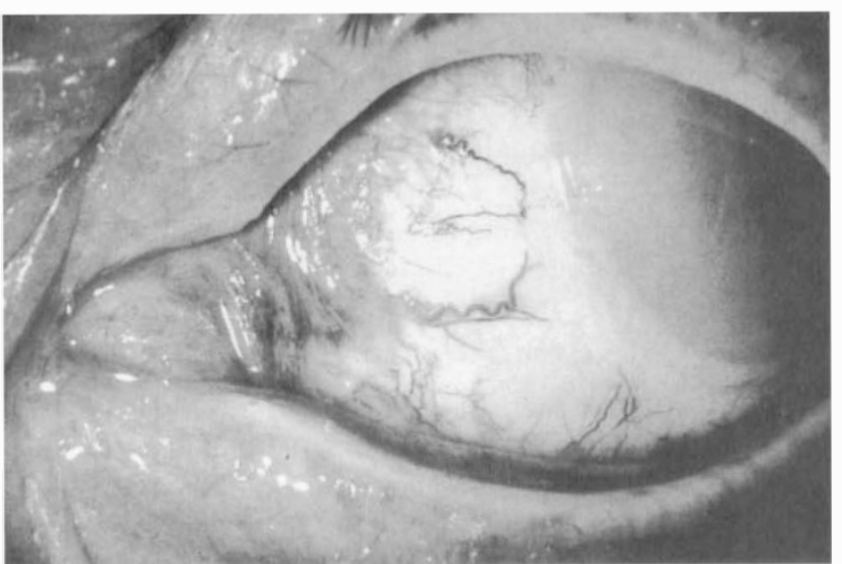

(a)

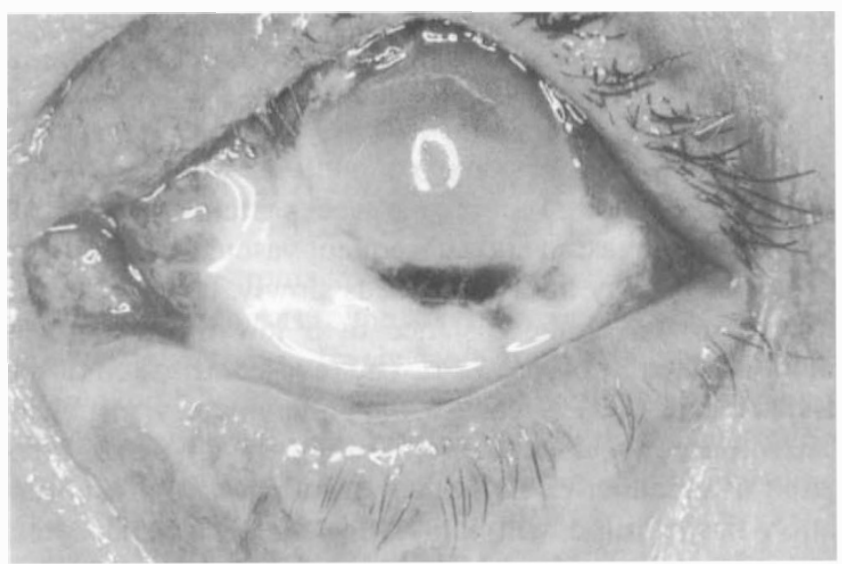

(c)

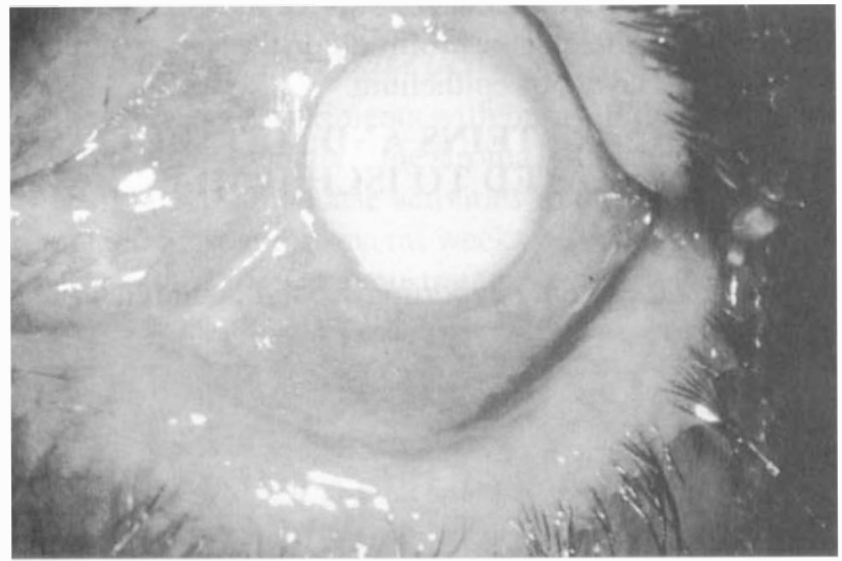

(e)

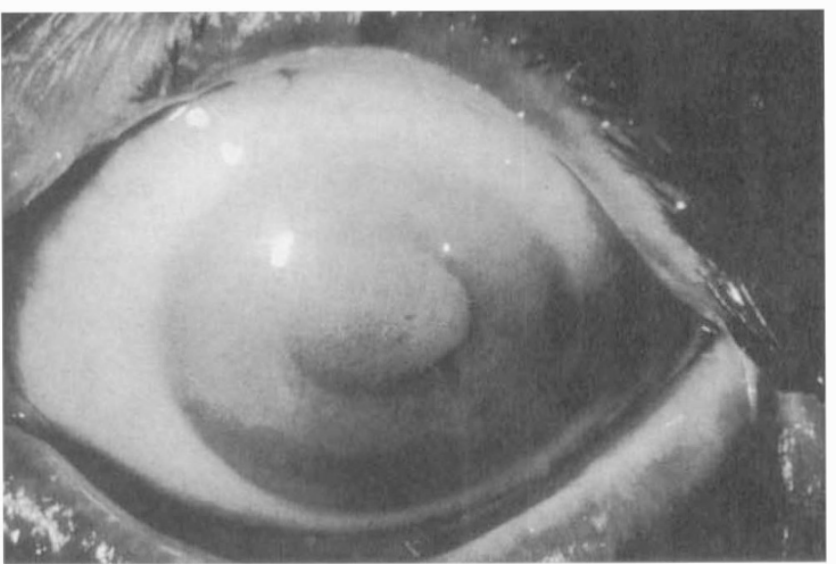

(b)

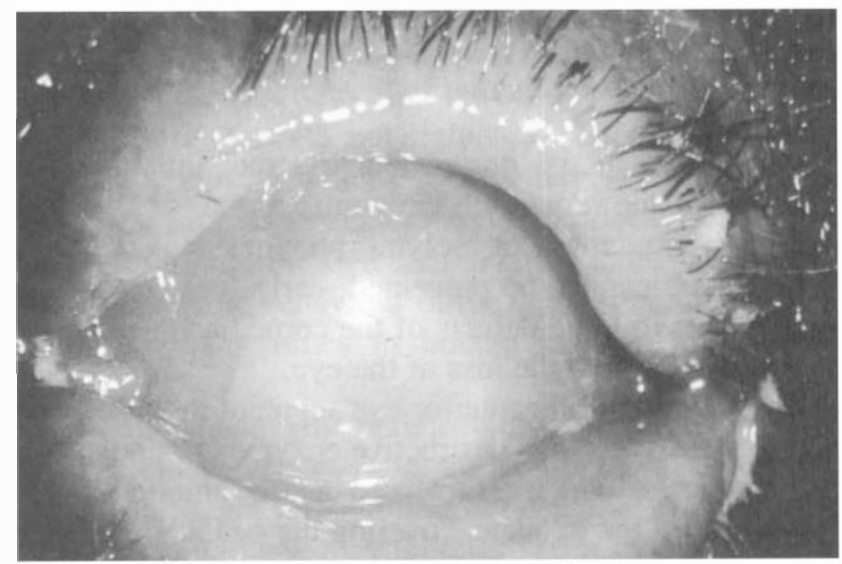

(d)

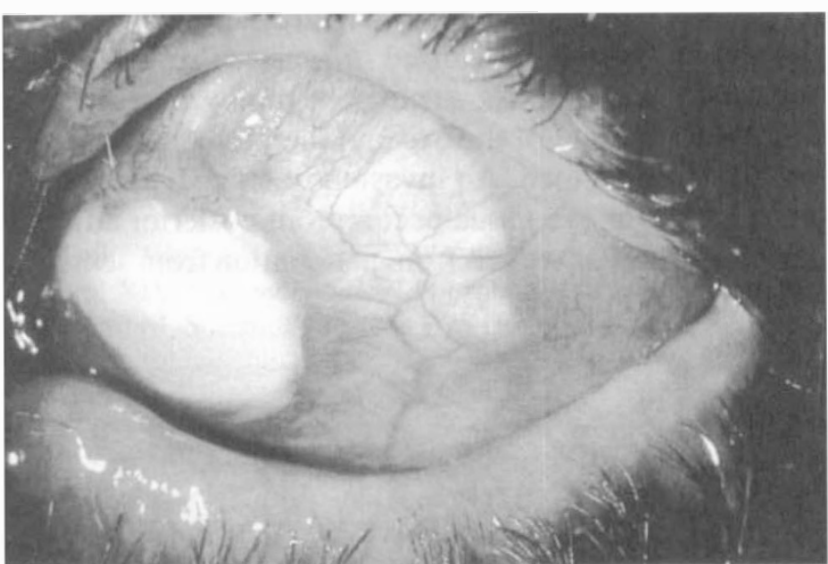

(f)

Fig. 2a-f. Development of an ischaemic anterior eye segment after a severe burn with $30 \% \mathrm{NaOH}$ (Patient J.P.). (a) Immediate necrosis; (b) 5 weeks later: Corneal turbidity and scleral ischaemia; (c) 11 weeks after the burn: Proliferation from conjunctiva and melting at the limbus; (d) 7 weeks after a corneal graft with scleral ring, inflamed proliferation tissue surrounds the cornea; (e) Appearance after 15 weeks following the corneal graft with scleral ring: Advancing proliferation tissue at the limbus and secondary calcification of the cornea; $(f) 6$ months later: The congestion of the conjunctiva was much better, but vascularised proliferation tissue from the limbus eroded the corneal graft.

The damage to the iris becomes apparent by its greyish colour, and an ectropion uveae which develops with the burn. The lens may also be affected and rapidly become turbid because the lens proteins have become liquified. Secondary glaucoma may be caused by the destruction of the trabecular meshwork and the outflow channels. How- ever, just as frequently the ischaemic lesion of the ciliary body will lead to ocular hypotony.

\section{INFLAMMATORY RESPONSE TO ISCHAEMIA}

Following the initial accident, the "eye burn disease" 


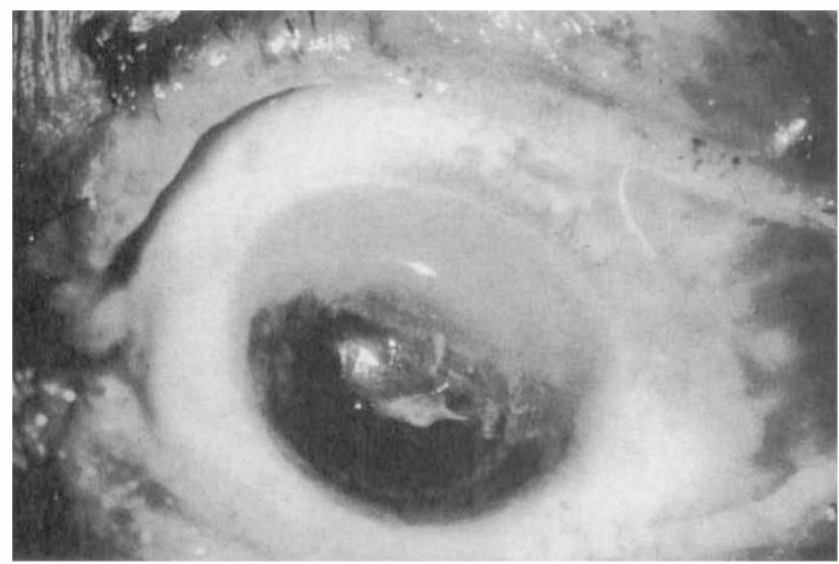

(a)

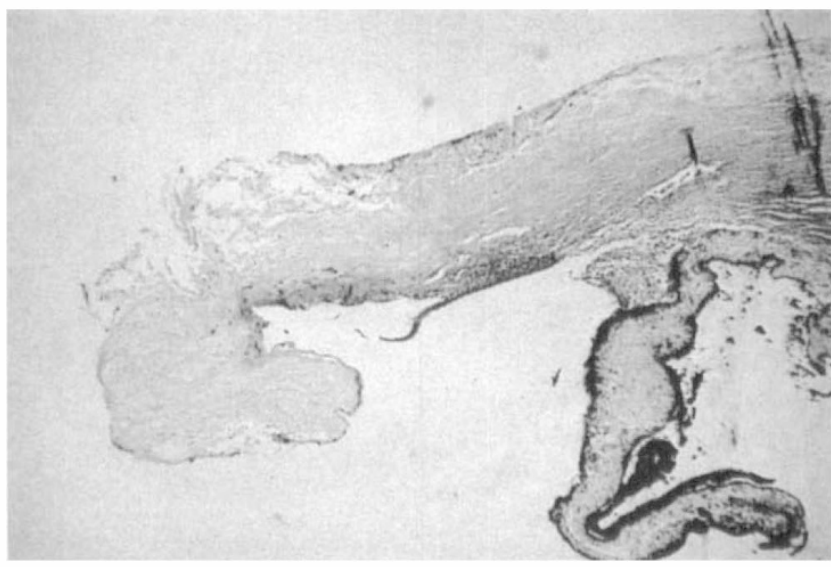

(b)

Fig. 3a-b. (a) Early melting of the corneal stroma by numerous leucocytes released with the exudate from the necrotic lid margins and tarsi 16 days after a severe liquid tin burn. (b) Histological picture of the melting tissues shown in Fig. $3 a$. The destroyed corneal stroma and the limbus acellular.

develops which is dominated by the inflammatory response of the remaining ischaemic tissue. ${ }^{3,4,5}$ If a considerable exudation of polymorphonuclear leucocytes appears and cannot be prevented, early melting occurs. This results in large defects of the cornea and sclera and eventually leads to the loss of the eye.

The melting of the anterior eye segment in these cases (Fig. 3a) is induced by destructive enzymes ${ }^{6,7,8}$ and superoxide radicals, ${ }^{9}$ which are released in large amounts by the leucocytes in the exudate, covering the ocular surface. In anterior segment ischaemia following severe burns, the corneal stroma and the sclera are acellular.

In contrast to necrotic conjunctival and subconjunctival tissues, which may be excised or repaired surgically, the acellular cornea and sclera cannot be removed as these tissues form the shell of the eye and therefore, maintain the integrity of the globe. An invasion of leucocytes into the burned anterior eye tissue occurs from posterior adjacent healthy tissues, as well as from penetration from secretion on the ocular surface.

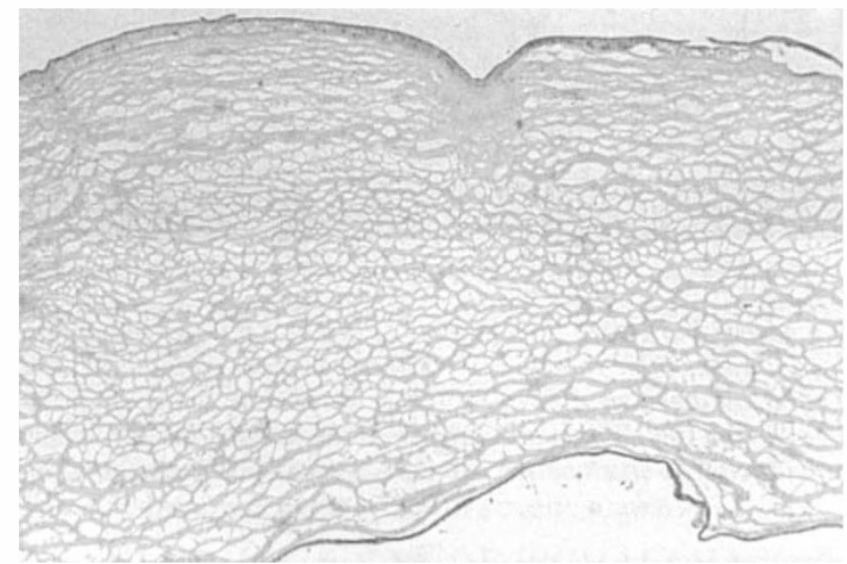

(a)
However, this invasion of cells into the cornea does not usually begin before four to six weeks after the injury and the cellular invasion and subsequent vascularisation from posterior healthy tissues proceeds slowly. It takes several months to cover the distance of a few millimeters as demonstrated in Figure 2a-c. The revascularisation of the ischaemic tissues is part of the inflammatory response. Therefore, this vascularised tissue is not a true regeneration of conjunctiva but rather an inflammatory proliferation tissue filled with polymorphonuclear leucocytes, macrophages, and lymphocytes. With increasing neovascularisation, fibroblast-like cells derived from the proliferation tissue, cover the ischaemic sclera and later the turbid cornea. Nevertheless, the proliferation tissue is covered by two or three layers of epithelium.

\section{SPECIFIC PROTEINS AND METABOLITES RELATED TO ISCHAEMIA}

\section{Fibronectin}

This specific protein supporting wound healing and epi-

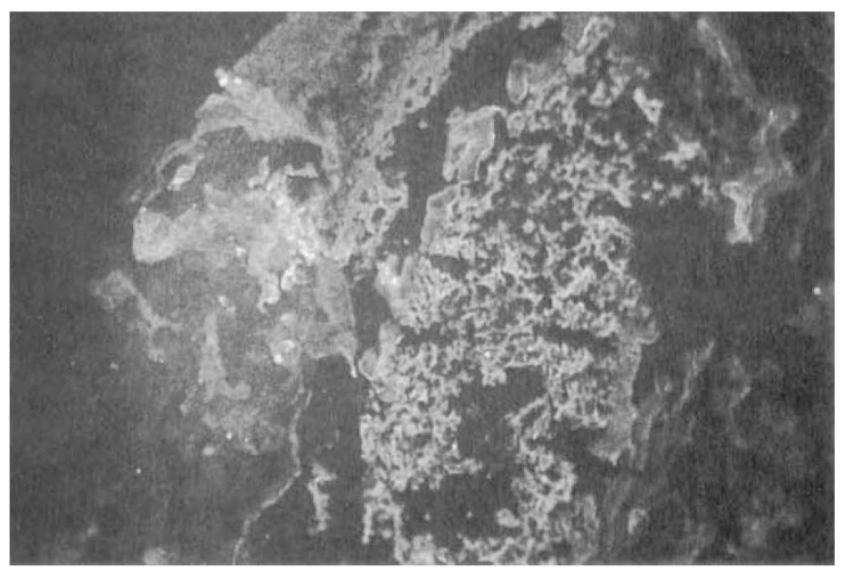

(b)

Fig. 4a-b. (a) Corneal stroma obtained from a graft in an eye six months following a severe burn with hot sulphuric acid. The stroma was oedematous and acellular. Stain hematoxolin-eosin, $\times 12,6$. (b) In many cases the acellular corneal stroma after burns did not contain any fibronectin, but it was found in the corneal stroma shown in Fig. 4 a. The patient was treated $4 \times$ daily with autologus fibronectin $(100 \mathrm{ug} / \mathrm{ml})$ for many weeks before the cornea was taken out for grafting. Fibronectin was stained with secondary antibodies marked with FITC. Magnification $\times 50$. 
thelial regeneration was found only in the surroundings of cells. ${ }^{10}$ In the acellular corneal stroma fibronectin was missing.

Topical treatment of the acellular ocular surface tissues with autologus fibronectin may substitute for the deficiency in these tissues (Fig. 4a and b).

\section{PLASMINOGEN ACTIVATOR AND PLASMIN}

In severely burned eyes, especially accompanying corneal and corneo-scleral ulceration, the activity of plasminogen activator and plasmin on the ocular surface was found to be elevated.

By contrast, when the eye was treated with topical proteinase inhibitor $\left(\right.$ Trasylol $\left.^{\circledR}\right)$, plasminogen activator activity was limited or missing and plasmin could not be found. ${ }^{11,12}$

\section{GLUCOSE, LACTATE, AND ASCORBIC ACID LEVELS IN THE CORNEA OF THE ISCHAEMIC EYE}

In the corneal stroma surrounded by ischaemic sclera following severe burns of the anterior eye segment with $1 \mathrm{~N}$ $\mathrm{NaOH}$, the glucose levels were markedly decreased as shown by. ${ }^{13,14 \text {, and } 15}$ Also, the lactate levels were decreased indicating that the glycolytic activity in the corneal tissue was reduced. In addition, the ascorbic acid disappeared from the anterior eye segment.

\section{ENZYME ACTIVITIES IN THE ISCHAEMIC ANTERIOR SEGMENT}

\section{$\mathrm{N}$-acetylglucosaminidase activity}

In the model of experiments with burns of the cornea and the adjacent conjunctiva, the stroma was mainly acellular. $\mathrm{N}$-acetylglucosaminidase activities in the corneal stroma remained normal for several weeks before cellular invastion began. ${ }^{7}$ It was demonstrated previously that in this type of burn the activity was mainly elevated in the corneal epithelium around persistent erosion or ulceration. ${ }^{16,17}$

Statistically however, significantly higher $\mathrm{N}$-acetylglucosaminidase activities were found in the conjunctiva surrounding the burnt cornea. Also, the activities of the $\mathrm{N}$-acetylglucosaminidase were increased in the conjunctiva after 21 days. At that time corneal ulceration became evident. ${ }^{17}$

In clinical cases of burns, which also extended to the tissues surrounding the cornea and developed ischaemia, samples were obtained from reconstructive surgery on these eyes, these ischaemic human tissue samples and acellular corneal lamellae also showed low activities of the $\mathrm{N}$-acetylglucosaminidase. But, as in the experimental model, the adjacent hyperaemic conjunctival tissue, especially in the later stages of the eye burn disease, revealed highly elevated $\mathrm{N}$-acetylglucosaminidase activities, which could be related to individual patients. ${ }^{18}$ As in the ischaemic tissues itself no cells were found that might have produced such high activities of $\mathrm{N}$-acetylglucosaminidase [Fig. 3b), it was assumed that the adjacent inflammatory proliferation tissue, filled with fibroblast-like and white blood cells, was the site of production of the enzyme. ${ }^{18}$

Cathepsin-D used for marker enzyme of proteolytic activity. Like $\mathrm{N}$-acetylglucosaminidase, in the conjunctiva surrounding the cornea the cathepsin-D activities were higher than in the cornea and elevated compared to normals. ${ }^{17}$

The most prominent clinical consequence of the anterior segment ischaemia following eye burns was the inability of the epithelium to regenerate. Although in severe burns of cornea and adjacent conjunctiva the epithelium of the anterior eye segment was completely destroyed and the conjunctival and subconjunctival tissue became necrotic, the corneal epithelium began to regenerate during the first days after the burn. ${ }^{16}$ The regeneration continued to the sixth and eighth day. Then the defects of the epithelium became larger. By day 10 following the burn, the process of regeneration and decay reached an equilibrium and the defects remained more or less constant. The same behaviour of the corneal epithelium was observed many times in human patients after severe burns. ${ }^{3,4}$

Destructive enzyme activities like $\mathrm{N}$-acetylglucosaminidase and cathepsin-D in the conjunctiva adjacent to ischaemia might have inhibited regeneration of the corneal epithelium and may therefore be responsible for the continuing destructive changes seen in many patients with burned eyes.

Key words: Cornea, Conjunctiva, Ulceration, $\mathrm{N}$-acetylglucosaminidase aminidase, Cathepsin-D, Glucose, Lactate, Regeneration, Epithelium, Rabbits, Human Cases.

\section{REFERENCES}

1. Duke-Elder S and MacFaul PA: System of Ophthalmology. Vol.XIV. Non mechanical injuries p.1010.

2. Reim M, Schmidt-Martens FW, Horster B, Schneidhauer E: Morphologische und biochemischel Befunde bei experimentellen Veraetzungen mit Alkali.Ber Dtschl.Ophthalmol. Ges 1982, 77, 749-59.

3. Reim M: Zur Pathogenese und Behandlung der Veraetzungskarnkheit. Bull.soc. Belge Ophthal 1980, 213: 41-61.

4. Reim M: Zur Behandlung schwerster Veraetzungen und Verbrennungen der Bindehaut. Fortschr. Ophthalmol 1987, 84: 65-9.

5. Reim M: Zur Pathophysiologie und Therapie der Veraetzungskrankheit Fortschr. Ophthalmol 1987, 84: 46-54.

6. Reim M: The clinical significance of proteolytic enzymes and glycosidases in corneal disease. Trans. Asian Pacific Acad. Ophthalmol, Vol. 3 edit T. Laetiangtong und S. Chotibutr; Phickanes Press, Bangkok, 1982, 3: 342-6.

7. Chayakul V and Reim M: Enzymatic activities of $\beta-N$ Acetylglucoseaminidase in the alkali burnes rabbit cornea. Graefes Arch Clin Exp Ophthalmol 1982, 18: 149-52.

8. Chayakul V and Reim M: The Enzymatic activities of $\beta-\mathrm{N}$ Acetylglucoseaminidase in the alkali burned rabbit cornea. Graefes Arch Clin Exp Ophthalmol 18: 145-8.

9. Becker J, Salla S, Reim M: Immuno histochemical investigations of tissue in most severe cases of eye burns. Documenta Ophthalmologica 1989, (In Press). 
10. Leber M, Knott H, Salla S, Steffens I, Reim M: Appearance and distribution of fibronectin in the cornea after severe alkali burn - an immuno fluorescence stdy. Ophthal Res $1989,221,338$.

11. Lund G, Becker J, Reim M: Investigation of inflammatory mediators in severe alkali burned rabbit corneas under therapy of a drug combination - "cocktail" therapy. Doc Ophthalmol 1990 (In Press).

12. Borchers H, Salla S, Reim M: Histological investigations after severe alkali burn of the rabbit cornea under therapy of a drug combination - "cocktail" therapy. Doc Ophthalmol 1990 (In Press).

13. Saric D and Reim M: Behandlung von Veraetzungen des vordern Augenabschnitts mit hochpolymereme Na-Hyaluronat (Healon). Forschr Ophthalmol 1984, 588-91.

14. Reim M and Saric D: Treatment of Chemical Burns of the Anterior Eye Segment with Macromolecular Sodium Hyaluronate (HEALON). Visco-Elastic Materials: Basic
Science and Clinical Application. edit. E. A. Balazs, Academic Press, London 1987, 41-52.

15. Reim M, Kaufhold FM, Kehrer Th, Kuckelkorn R, Kuwert T, Leber M: Zur Differenzierung der Therapie bei Verätzungen-eine biochemische und histologische Studie mit Konsequenzen für die Klink. Nova Acta Leopoldina 1985, 57: 77-94.

16. Reim M, Chayacul V, Hecking P, Radling-Meyer B, Schmidt-Martens FW: Experimentelle Verätzungen eine biochemische und histologische Studie mit Konsequenzen für die Klinik. Nova Acta Leopoldina 1985, 57: 77-94.

17. Reim $M$ and Bahrke $C$ : Investigation of enzyme activities in severe burns of the anterior eye segment. A von Graefés Arch Klin Exp Ophthalmol 1992 (In Press).

18. Reim $\mathrm{M}$ and Leber $\mathrm{M}: \mathrm{N}$-acetylglucosaminidase activities in corneo-scleral ulceration following severe eye burns related to individual patients. Cornea 1992 (In Press). 